\title{
SH3 and Multiple Ankyrin Repeat Domains Protein 3
}

National Cancer Institute

\section{Source}

National Cancer Institute. SH3 and Multiple Ankyrin Repeat Domains Protein 3. NCI

Thesaurus. Code C75401.

SH3 and multiple ankyrin repeat domains protein 3 (1731 aa, 185 kDa) is encoded by the human SHANK3 gene. This protein is involved in the formation and maintenance of dendrites and synapses. 